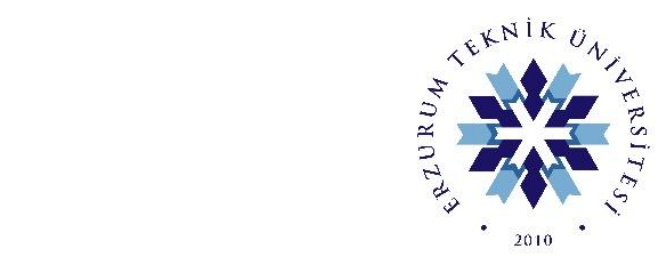

\title{
TÜRKİYE'DE HAYVAN YAŞAM KALİTESİ MEVZUATI VE UYGULAMALARI
}

QUALITY OF ANIMAL LIFE AND APPLICATION IN TURKEY

KIVANÇ DEMIRCI

Doktora Öğrencisi, Dokuz Eylül Üniversitesi, Kamu Yönetimi Bölümü

kivancdemirci4@gmail.com

iD https://orcid.org/0000-0001-6598-6673

\author{
ETÜ Sosyal Bilimler Enstitüsü Dergisi |ETU Journal of Social Sciences Institute \\ S.9, Ekim | October 2019, Erzurum \\ ISSN: 2149-939X \\ Makale Türü | Article Types ： Araştırma Makalesi | Research Article \\ Geliş Tarihi|Received Date $\quad$ : 17.12 .2018 \\ Kabul Tarihi|Accepted Date $\quad$ : 02.08.2019 \\ Sayfa|Pages : $1-16$ \\ do) : http://dx.doi.org/10.29157/etusbe.118
}

www.etusbe.com

https://dergipark.org.tr/etusbed

This article was checked by

$\checkmark$ iThenticate 



\title{
TÜRKIYYE'DE HAYVAN YAŞAM KALITTESİ MEVZUATI VE UYGULAMALARI
}

\author{
Kıvanç DEMİRCI \\ ETÜSosyal Bilimler Enstitüsü Dergisi (ETÜSBED), S.9, Ekim 2019, Sayfa: 1-16
}

\section{ÖZ}

Kentsel ve kırsal alanlarda hayvan ve insan popülasyonlarında meydana gelen değişikler sonucu karşılıklı olarak zarar gören insan ve hayvanların zararlarının önlenmesi amacıyla gerek uluslararası gerekse ulusal düzeyde çeşitli mevzuat hükümleri yürürlüğe konulmuştur. Bu noktadan hareketle 15 Ekim 1978 tarihinde ilan edilen Hayvan Hakları Evrensel Beyannamesi hayvan haklarına genel bir bakış açısı getirmesi insan ve hayvanların birbirlerinden gördükleri karşılıklı zararların önlenmesi açısından büyük önem taşımaktadır. Bu beyanname ile bağlantılı ülkelerin kendi egemenlik sinırları içerisinde yürürlüğe giren ulusal mevzuat hükümleri ve bu hükümlerin uygulanmasının incelenmesi araştırma için önemli bir noktayı oluşturmaktadır.

Geçmişten günümüze Türkiye'de hayvan haklarıyla ilgili önemli gelişmeler kaydedilmiştir. 2004 yılında yürürlüğe giren 5199 sayılı Hayvanları Koruma Kanunu bu gelişmelerin somut bir çıktısı olup araştırmanın mantıksal çerçevesini oluşturmaktadır. Bu noktadan hareketle araştırmada Türkiye'de yürürlükte olan hayvan yaşam kalitesiyle ilişkili mevzuat hükümlerine değinilecektir. Ayrıca mevzuat kaynaklı sorunların tespit edilmesi ve mevcut sorunlara yönelik çözüm önerileri getirilmesi de amaçlanmıştır.

Anahtar Kelimeler: Hayvanları Koruma Kanunu, Hayvan Hakları Evrensel Beyannamesi, Kentsel ve Kursal Alan.

\section{QUALITY OF ANIMAL LIFE AND APPLICATION IN TURKEY}

\begin{abstract}
Due to the increasing number of animals in urban and rural areas, various legislative provisions have been put into practice at the international and national level in order to prevent people and animals from getting mutually damaged. Based on this fact, the Universal Declaration of Animal Rights, which was announced on the 15th of October 1978, is of great importance since it sheds light on animal rights and aims to prevent people and animals from getting mutually harmed. Provisions of national legislation enacted under the sovereignty of the countries associated with this declaration and the examination of the implementation of these provisions constitute an important point for the research.

Significant developments related to animal rights in Turkey have been recorded from past to present. Being the concrete output of these developments, The Law no. 5199 on the Protection of Animals, which came into force in 2004, constitutes the logical framework of the research. From this point of view, legislations, which are in force in Turkey, related to the quality of life of animals will be discussed in the research. In addition, the determination of problems resulting from legislation and providing solutions to those problems will be aimed.
\end{abstract}

Keywords: Animal Protection Law, Universal Declaration of Animal Rights, Urban and Rural Area. 
Giriş

İnsanlar, Cilalı taş devrinde, avcı toplayıcı hayattan üretim yapabilme amacıyla yerleşik hayata geçerken, bu üretim süreçlerinde kullanma amacı ile çeşitli hayvanları evcilleştirmişlerdir. Bireyler evcilleştirilmiş olan hayvanları temel olarak barınma, beslenme ve korunma ile ilgili ihtiyaçları karşılamak için kullanmışlardır. Buna ek olarak ise çiftlik hayvanlarından ise süt, et, yumurta gibi çeşitli besin maddeleri elde etmişlerdir. Bu örneklerden de görüldüğ̈ü üzere neolitik dönemde, insan-hayvan ilişkisinin büyük oranda ekonomik kapsamda olduğu görülmektedir (Pounting, 2008).

18. yüzyıl Sanayi Devrimi'nin etkilediği günümüzün modern kentlerinde ise, insan ile hayvanlar arasındaki ilişki farklılaşmış, üretkenliğin, verimliliğin, uzmanlığın ön planda olduğu kentlerde, ekonomik ilişkiler yerini insan ve hayvanların birbiriyle arkadaş/dost olduğu ilişkilere bırakmıştır. 21. yüzyılda ise insan ve hayvanlar arasındaki arkadaşlık ilişkileri daha ileri bir seviye olan aile bireyliğine kadar götürülmektedir (Tamzok, Kük, \& Çobanoğlu, 2013).

Ekolojik dengenin en önemli halkalarından biri olan aynı zamanda bireylerle olan ilişkileri nedeniyle doğal çevrenin en önemli unsurlarından biri olan hayvanların bazı haklara sahip olması ve bunların hukuk alanında korunması düşüncesi diğer hakların korunması düşüncesine göre yenidir. Hayvanları koruma düşüncesi ekolojik dengenin bozulmasının yanında insan hayatını doğrudan etkilemesi nedeniyle gündeme gelmeye başlamıştır

Bu bağlamda Modern Avrupa'ya bakıldığında hayvan haklarını güvenceye alan yasal düzenlemeler 18. yüzyılda yürürlüğe girmiş olmasına karşın Türkiye' de temel anlamda hayvan haklarına yönelik yasal düzenlemeler 20. yüzyılın sonu ve 21 . yüzyılın başına denk gelmektedir. Türkiye'deki hayvan haklarıyla ilişkilendirebileceğimiz bu mevzuat hükümlerinin bir kısmı dolaylı bir kısmı ise doğrudan hayvan haklarını koruyucu hükümler içermektedir. Türkiye'de hayvan haklarını yasal bir zemine dayandırma çalışmalarıyla ilişkilendirebileceğimiz TC. Anayasası maddeleri, kanunları ve kanun hükmünde kararnameleri ayrıntılı olarak incelenecektir.

\section{HAYVAN YAŞAM KALİTESİYLE DOĞRUDAN İLIŞSİLENDİRILEBİ- LECEK MEVZUAT HÜKÜMLERİ}

\subsection{Türkiye Cumhuriyeti Anayasası (09.11.1982)}

Türkiye' de hayvanların yaşam kalitesi denildiğinde ilk olarak Anayasanın 169. maddesine bakılması gerekmektedir. Bu maddeye göre;

"Devlet, ormanların korunması ve sahalarının genişletilmesi için gerekli kanunları koyar ve tedbirleri alır. Yanan ormanlarn yerinde yeni orman yetiştirilir, bu yerlerde başka çeşit tarım ve hayvancılık yapılamaz. Bütün ormanların gözetimi Devlete aittir." (Türkiye Büyük Millet Meclisi, 1982). 
$\mathrm{Bu}$ madde de orman varlığına ve orman alanları içerisindeki fauna ve flora ortamının korunmasına özel bir önem verildiği görülmektedir $\mathrm{Bu}$ maddenin yürürlüğe girmesiyle beraber devlet ülke sınırları içerisindeki ormanları ve ormanların içerisinde bulunan orman ekosistemini korumayı kendisine görev olarak kabul etmiştir (Yılmaz, 2006). Ormanlar içerisinde yaşayan canlı türleriyle birlikte ele alındığında ormanların korunması dolaylı bir şekilde içerisindeki ekosistemi de koruyacağından dolayı bu madde hayvanların korunması açısından özel bir önem teşkil etmektedir (Ege Orman Vakf1, 2015, s. 13).

\subsection{Türk Ceza Kanunu (12.10.2004)}

Hayvan hakları denildiğinde bakılması gereken ikinci önemli kaynak 5237 sayılı Türk Ceza Kanunu'dur. TCK'nın 151. maddesinde mala zarar verme başlığı altında başkasına ait olan taşınır veya taşınmaz olan eşyayı nedensiz yere bozan, tahrip eden, kullanılmaz hale getiren kişiye mağdurun şikâyeti üzerine 4 ay ile 3 yıl arasında hapis cezası veya adli para cezası öngörülmüştür. Yine aynı maddenin ikinci fıkrasında geçerli olan cezalar haklı bir neden olmadan sahipli bir hayvanı öldüren ya da sahipli hayvanın değerinin düşmesine neden olacak davranışta bulunan kişiye de öngörülmüştür (TBMM, 2004).

Üçüncü kişiler tarafından sahip olunan hayvana karşı yapılan zarar verici davranış sonucunda hayvanın sahibi savcilığa suç duyurusunda bulunduğunda yargılama 151. maddeye göre yapılmaktadır. Ceza Kanunu'nun bu maddesinde ifade edilen hayvanlara karşı suç şikâyete dayalı bir yargılama gerektirdiğinden savcılığa kendiliğinden soruşturma açma yetkisi verilmemiştir. Hayvana yukarıda belirtilen şekilde davranışta bulunan üçüncü kişi sahiplik sıfatı taşıyan kişiye karşı maddi zararı karşılaması durumda dava düşmektedir (Albayrak, 2008). TCK'nın oldukça tartışlan bu maddesinde hayvanlara ilişkin ayrıma gidildiği görülmektedir. İlgili maddede görüldüğü gibi hayvana karşı işlenecek bir suçun soruşturmaya yol açması için hayvanın bir sahibinin olması gereklidir. Sahipsiz bir şekilde doğada kendi ortamında yaşayan bir canlının öldürülmesi sonucunda öldüren kişinin bu madde kapsamında yargılanması mümkün değildir (TBMM, 2004).

Türk Ceza Kanun'unda geçen haklı bir neden ifadesinde hangi nedenlerin haklı olarak değerlendirilebileceği açıkça sıralanmamış olup yorum yöntemi kullanılarak haklı nedenler hukuka uygunluk hallerinden olan meşru müdafaa ve zaruret hali olarak ifade edilmiştir (Gürocak, 2011). Türk Ceza Kanunu'nun yukarıda belirtilen ilgili maddeleri sahipli - sahipsiz hayvan ayrımı yapmamalıdır. Hayvanların yaşam kalitesinin tam olarak sağlanması için tüm hayvanların menfaati göz önünde bulundurulmalıdır.

TCK'nın çevrenin taksirle kirletilmesi başlıklı 182. maddesinin birinci fıkrasında “Çevreye olumsuz etkide bulunabilecek şekilde atıkların doğaya bırakılması 
sonucunda doğanın zarar görmesine neden olan kişiye adli para cezası; bu bırakılan atıkların doğaya kalıcı zarar vermesi durumda ise kişi 2 aydan 1 yıla kadar hapis cezası ile cezalandırılır" hükmü bulunmaktadır. İkinci fıkrasında ise doğaya bırakılan artıklarla insan veya hayvan sağlığında kalıcı hasarların ortaya çıkmasına, üreme kabiliyetlerinin kaybına neden olan kişi 1 yıldan 5 yıla kadar hapis cezasına çarptırılır. Türk Ceza Kanunu'nun bu bağlamda insanlarla birlikte hayvanları da korumasına ek olarak TCK'da hayvanlarla ilgili en belirgin suç tipi bu maddede tanımlanmıştır (Özmen, 2012).

Türk Ceza Kanunu'nun hayvanları koruma konusuyla ilişkilendirilebilecek diğer bir maddesi de 226. maddesidir. Bu maddenin dördüncü fikrasında "Hayvanlarla insanlar arasında şiddet ve zor yoluyla doğal olmayan şekilde cinsel davranışlar içeren görüntü, ses ve yazı kayıtlarını ülke içerisine sokan, çoğaltan, satan ve bulunduran kişilere 1 yıl ile 5 yıl arası hapis ve üst sınırı beş bin gün olacak şekilde idari para cezası verileceği" hükme bağlanmıştır (TBMM, 2004). Bu maddeye göre insanlar ile hayvanlar arasındaki cinsel eylemlerin belirli araçlarla kayıt altına alındıktan sonra saklanıp, kopyalanması aşamaları suç olarak düzenlenmiştir. Bu maddenin yürürlüğe girme amacı bu tip görüntülerin toplumun genel ahlak yapısında ve kamu düzenine olumsuz etkide bulunmaması ayrıca bu tip eylemlerin yaygınlaşmasını önlemek şeklinde ifade edilmektedir (Dönmez, 2013).

Bu kapsamda hayvanlara cinsel saldırı suçu açısından Türk Ceza Kanunu'nun 102. maddesi önem taşımaktadır. Bu madde de: "Cinsel davranışlarla bir kimsenin vücut dokunulmazlığını ihlâl eden kişi, mağdurun şikâyeti üzerine, beş yıldan on yıla kadar hapis cezası ile cezalandırılır." hükmü bulunmaktadır. Buna göre cinsel saldırı suçuna maruz kalan hayvan veya ölmüş bir kimse olmamalıdır (Gürkan \& Uğuz, 2007). Cinsel saldırı suçuna maruz kalan yaşamını devam ettiren bir insan olmalıdır. Bu maddeye göre Türk Ceza Kanun'unda hayvanlara yönelik cinsel saldırı suçu düzenlenmemiştir. Hayvanlara yönelik cinsel saldırı suçu 5199 sayılı Hayvanları Koruma Kanun' unda belirtilmiştir (Parlar \& Hatipoğlu, 2007).

\subsection{Hayvanları Koruma Kanunu (24.06.2004)}

5199 sayılı Hayvanları Koruma Kanunu Türkiye'de hayvanların korunması konusunu düzenleyen en temel kanundur. Kanun ceza niteliği ve yaptırımlar taşıyan tipik bir ceza kanunu olarak düşünülmemelidir. Bu kanun kabahatler kanunu olarak oluşturulan yasal bir düzenlemedir. Yani kanunda belirtilen hükümlere aykırı davranan kişi veya kurumlar mahkemelerce yargılanmamakta, para cezalarıyla cezalandırılmaktadırlar (Özgür, 2010). Kanun bu özelliği nedeniyle caydırıcı cezalar öngörmemektedir. Öngörülen düşük para cezaları kanunda belirtilen yasaklar için caydırıı bir özellik taşımaktan uzak kalmaktadır. Hayvanların yaşam kalitesinin arttırılması için kanunda belirtilen yasaklara uygun olarak hapis veya daha yüksek para cezalarının hükme bağlanması gerekmektedir. 


\subsubsection{Genel Hükümler}

5199 sayılı kanunun temel amacı hayvanlara iyi muamele edilmesini sağlamak, acı ve 1stıraba karşı korumak ve bunlar dışında mağdur oldukları konularda mağduriyetlerinin giderilmesi olarak ifade edilmiştir. Kanunun 4. maddesinde yer alan ilkeler kısmında ise hayvanların yaşam kalitesinin geliştirilmesi ve böylelikle daha rahat bir yaşam sürmesi için gerekli olan temel unsurlar aşağıda yer almaktadir;

1. Tüm hayvanlar eşit bir şekilde doğar ve bu hayvanlar hiçbir fark gözetmeksizin yaşama hakkına sahiptir.

2. Ev ortamında yaşayan hayvanların kendi doğal yaşam şartları içerisinde yaşama hakları bulunmaktadır. Sahipli hayvanlara gösterilen önem sahipsiz hayvanlara da verilmelidir. Sahipli - sahipsiz hayvan ayrımı yapılmamalıdır.

3. Yaşayan tüm hayvanların bakımı, korunması ve acı verici davranışlardan uzak tutulması için uygun önlemler alınmalıdır.

4. Maddi ve manevi hiçbir yarar sağlamamak şartıyla sahipsiz ve güçten düşmüş hayvanların bakımının sağlanması için kanunda belirtilen şartları taşıyan gerçek veya tüzel kişiler teşvik edilmeli ve bu kişilerle eşgüdüm sağlanmalıdır.

5. Nesli tükenme tehlikesi ile karşı karşıya olan hayvanların korunması sağlanmalıdır.

6. Yabani bir yaşam süren hayvanların doğal hayatından uzaklaştırılmaması ve doğada kendi çevresinde yaşayan bir hayvanın özgürlüğünü kısıtlayıcı veya mahrum edici davranışlarda bulunulmaması esastır.

7. Hayvanlar kendi türünün gerektirdiği şekilde yaşamaya alışkın oldukları çevrede ihtiyaçları karşılanmalıdır. Bu ihtiyaçları karşılanırken güvenlikleri, hijyen şartları, sağlıkları ve duyguları dikkate alınmalıdır.

8. Yerel yönetimler, gönüllü kuruluşlar ile birlikte sahipsiz ve yardıma muhtaç hayvanların bakılması amacıyla hayvan bakımevleri ve hastaneler kurmalıdır.

9. Yerel yönetimlerin sınırları içerisinde hayvanların korunması, bakılması ve acı çekmesini önlemeye yönelik halkı eğitici faaliyetlerde bulunacak etkinlikler düzenlemesi esastır.

10. Hayvanların kontrolsüz bir şekilde çoğalmasının önlenmesinin önüne geçilmesi için toplu olarak yaşanılan alanlarda kedi ve köpeklerin sahiplerinin kontrolünde kısırlaştırılması esastır. Buna karşın doğacak olan yavru bulunması halinde ise hayvan sahibi doğacak yavrunun kayıt altına alınması için belediyeye başvuru yapmalıdır (TBMM, 2004).

Özellikle hayvanların yaşama hakkının olduğunun kabul edilmesi ve yok olma tehlikesiyle karşı karşıya kalan hayvanların korunması gibi Hayvan Hakları Evrensel Beyannamesiyle uyumlu olarak benimsenen bu ilkeler hayvan yaşam 
kalitesinin arttırılması konusunda Türkiye'de atılan önemli adımların başında gelmektedir. Fakat bu kanunun kabahatler kanunu kapsamında olması ve TCK ile arasında bütünlüğün olmaması nedeniyle işlevselliğini kaybetmektedir. Hayvanları Koruma Kanun'unda sahipli sahipsiz hayvan ayrımı yapılmaması ifade edilirken yukarıda bahsettiğimiz Türk Ceza Kanun'unun 151. maddesi sahipli ve sahipsiz hayvan ayrımı yapmaktadır. Yürürlüğe giren kanunlar arasında bir uyumun olması hukuki sistemde kargaşanın çıkmasını önleyecektir. Bundan dolayı bu iki kanun arasındaki farklı ifadelerin düzeltilmesi gerekmektedir (Özgür, 2010).

\subsubsection{Hayvanların Sahiplenilmesi, Bakımı ve Korunması}

Hayvanların sahiplendirilmesi ve bakımı başlığı altında genel hükümlerinde verilen hayvanların alışık olduğu yaşam ortamından uzaklaştırılmaması ifadesi tekrarlanmıştır. Kanunun 5. maddesi ev ve süs hayvanı satan kişilerin yerel yönetimlerce düzenlenecek eğitim programlarından sertifika almasını zorunlu kılmıştır (TBMM, 2004). Yine aynı maddede ev ve süs hayvanı satan yerlerden veya başka yollarla hayvan sahiplenen kişiler sahip oldukları hayvanı yaşamını devam ettiremeyeceği bir ortama bırakmaları yasaklanmıştır. Kanunun 6. maddesi'nde ise kendi ihtiyaçlarını karşılama yeteneğini kaybetmiş derecede güçten düşmüş ve sahipsiz hayvanların öldürülmesi yasaklanmıştır. $\mathrm{Bu}$ durumda bulunan hayvanların yerel yönetimler tarafından kurulan hayvan hastaneleri veya bakımevlerine ulaştırılması zorunludur. $\mathrm{Bu}$ merkezlere ulaştırılan hayvanların kısırlaştırma, aşılama ve bakım işlemleri yapıldıktan sonra alındıkları çevreye bırakılması esas olarak kabul edilmiştir (TBMM, 2004).

\subsubsection{Hayvanlara Cerrahi ve Yasak Müdahaleler}

Kanun bu başlık altında hayvanlara zarar verici maddeler (bıçak, sopa vb.) kullanılarak gereksiz şekilde acı çektirilmesinin önüne geçmeyi amaçlamıştır. Kanunun 7. maddesi bu amaç kapsamında kabul edilmiş olup hayvanlara veteriner kontrolü olmadan yapılan her türlü cerrahi müdahaleyi yasaklamıştır. Hayvanların hayati fonksiyonları devam ettiği sürece sahip oldukları organların tıbbi amaçlar dışında alınamayacağını ve hayvanın yaşamını etkileyecek şekilde tahrip edilemeyeceği vurgulanmıştır. Hayvan üzerinde tedavi niteliği taşımayan kuyruk kesme, ses tellerinin alınması, tırnaklarının yapısının bozulması gibi müdahaleler yasaklanmıştır. Bu tip tedavi amacı taşımayan yöntemlere yalnızca hayvanın menfaatinin sağlandığı durumlarda izin verilebileceği hükme bağlanmıştır (TBMM, 2004).

Bu maddeye uymayan kişilere 1.200 Türk Lirası ceza verilmesi 5199 sayılı Kanun'da hükme bağlanmıştır. Bu hükmün varlığına rağmen sahip oldukları köpekleri daha saldırgan yapmak amacıyla kuyruklarını kesen bireylerin hiçbir ceza almadan bu eylemlerine devam ettikleri görülmektedir. Bu durumlarla daha fazla karşı karşıya kalınmaması için belediyelerin denetim mekanizmalarının arttııılması 
gerekmektedir. Belediye bünyesinde çalışan kişiler ve o bölgede yaşayan yerel halkın bu tip hukuka uygun olmayan eylemleri gerçekleştiren kişilere karşı gerekli davranışları göstermesi gerekmektedir. Yerel halk bölge de bulunan Tarım ve Orman Bakanlığı Müdürlüklerine şikâyet dilekçesini verebilir. Böylece bu tip eylemlerin tekrarlanmasını engelleyebilir. Kanunun hayvan deneyleriyle ilgili olan 9. maddesi ise en önemli düzenlemelerin başında gelmektedir. Maddenin ilk fıkrasında hayvanların bilimsel olmayan hiçbir deneyde ve tedavi yöntemlerinde araç olarak kullanılmayacağı ifade edilmiştir (TBMM, 2004). Bilimsel amaçlı deneylerde ise hiç bir seçenek kalmadığı durumlarda hayvanların kullanılabileceğini hükme bağlanmıştır. Bilimsel amaçlı deneylerde kullanılan hayvanların uygun bir şekilde bakılması ve deneyin hayvana acı vermeyecek şekilde yapılması gerekliliği yine aynı maddede belirtilmiştir. Bilimsel amaçlı hayvan deneyi yapan kuruluşlar bünyesinde kurulan etik kurullar bu deneylerin yapılıp yapılmayacağına karar vermektedir. Bu yolla etik olmayan deneylere karşı hayvanların korunması amaçlanmıştır. Ancak 5199 sayılı Kanun'daki bu hüküm hayvanların deneylerde kullanılmasını engelleyecek bir nitelik taşımamaktadır. Etik kurullar tarafından belirlenecek neden tamamen bu kuruldaki insanların vicdanlarına bırakılmıştır. Bununla birlikte bilimsel amaçlı deneylerin belirli bir sınırı çizilmemiştir. Bu madde insanlar için zorunlu olmayan bir buluşun sırf bilimsel bir gelişme niteliği taşıdığı için hayvanlar üzerinde test edilebileceği yorumunu barındırmaktadır.

1.3.4. Yerel Hayvan Koruma Kurullarının Teşkilât Yapısı, Görev ve Sorumlulukları

Hayvanları Koruma Kanunu'nun 15. maddesine göre her ilde Vali'nin başkanlığında Hayvanları Koruma Kurulu toplanır. Kurulun toplanma amacı hayvanların sorunlarının çözümü için projeler gerçekleştirmek ve hayvanların korunmasını sağlamaktır. Hayvanlar Koruma Kurulu tarafından gerçekleştirilen toplantılara, il büyükşehir statüsünde ise büyükşehir belediye başkanı ve ilçe belediye başkanları, büyükşehir statüsünde olmayan illerde ise belediye başkanlarına ek olarak Çevre ve Şehircilik İl Müdürü, Tarım ve Orman işleri İl Müdürü, İl Sağllk Müdürü, İl Milli Eğitim Müdürü, İl Müftüsü, Belediyelerin Veteriner İşleri Müdürleri, Valilik takdiriyle hayvanları koruma konusunda il içerisinde faaliyet gösteren gönüllü kuruluşlardan en çok iki kişi ve ile veya bölge veteriner odasından bir temsilci katılır (TBMM, 2004).

Hayvanları Koruma Kurullarının görevleri, hayvanların korunmasında ve kullanılma aşamalarında Hayvanları Koruma Kanunu'nda verilen sorumlulukları yerine getirmek, bağlı oldukları il sınırları içerisinde bulunan hayvanların sorunlarını belirleyip çözüm önerileri getirmek, hayvanların korunmasıyla ilgili çözüm önerilerini de barındıran bir, beş ve on yıllık projeler gerçekleştirmek, hayvanların korunmasıyla ilgili il sınırları içerisinde faaliyet gösteren kuruluşları 
yönlendirmek koruma konularıyla ilgili eşgüdümü sağlamak, hayvan sevgisini aşılayıp sorunlarının çözümü için uygun eğitim faaliyetleri düzenlemek ve diğer mevzuatla verilen görevleri gerçekleştirmek olarak sayılabilir (TBMM, 2004).

\subsubsection{Hayvanların Kesimi, Öldürülmesi ve Yasakları}

Hayvanları Koruma Kanunu bu başlık altında hayvanlara yapılması yasaklanan eylemleri 12 madde halinde sıralanmıştır. Bu yasaklar şu şekilde özetlenebilir:

1. Hayvanlara acı verici eylemler yapılması, aç ve susuz bırakmak, fiziksel ve psikolojik acı verici eylemlerde bulunmak,

2. Hayvanların fiziksel gücünün imkân vermediği işleri yapmaya zorlamak,

3. Yerel yönetimlerden hayvan bakımı eğitimi almamış kişilerden hayvan satın alınması,

4. 16 yaşın altındaki kişilere hayvan satışının yapılması,

5. Belirli kontroller yapılmadan hayvanın tam olarak öldüğünü anlaşılmadan vücutları üzerinde herhangi bir müdahalede bulunulması,

6. Kesim amacıyla yetiştirilen, 4915 sayılı Kara Avcılığı Kanunu kapsamında avlanmasına izin verilen ve ticaret amacıyla kullanılabilen hayvanlar dışındaki hayvanları et ihtiyacının karşılanması için kesilmesi ve piyasaya verilmesi,

7. Kesim amacı dışında yetiştirilen hayvanların ödül veya ikramiye olarak verilmesi,

8. Hayvanlara, hayvanların karınlarındaki yavrularına veya havyar üretimi amacı dışında yumurtalara zarar verecek tıbbi müdahalelerin dışındaki müdahaleler,

9. Gebelik süresinin $2 / 3$ ünde bulunan hayvanların gebeliğine zarar verecek koşullarda çalıştırılması,

10. Hayvanlara işkence yapılması ve hayvanlarla cinsel ilişkide bulunulması,

11. Hayvanlara sigara, alkollü içki gibi sağllğa zararlı maddeleri içirtmek ve zor kullanarak gerekli olmadığı halde fazla besin almasına neden olmak,

12. İnsanlar için tehlike taşıyan türleri ülkeye sokmak dağıtımını ve satışını yapmak (TBMM, 2004)

Yukarıda sayılan bu yasaklara aykırı davranan kişilere idari para cezası dışında hiçbir ceza hükme bağlanmamıştır. Bu durumda Hayvanları Koruma Kanunu'nun suç niteliği taşıyan bir kanun olarak değil kabahat şeklinde idari para cezaları veren bir kanun olarak düzenlendiğini göstermektedir. (Erişgin \& Koçhisarlığlu, 2003) Yukarıda hükme bağlanan cezaların caydırıcılığının düşük olduğu görülmektedir. Halk üzerinde caydırıcılığının arttırılması için bu cezaların daha yüksek para veya hapis cezalarıyla değiştirilmesi gerekmektedir. 
Hayvanların kesimi alt başlığı altında ise dini hassasiyetler dikkate alınarak hayvanlara acı ve korku duygusunu yaşatmadan kesim işlemlerinin yapılması gerektiği vurgulanmıştır (TBMM, 2004). Kanundaki dini hassasiyetler ibaresi oldukça ucu açık bir ifadedir. Bu gibi hükümlerin hayvan haklarını sekteye uğratabileceğinden, ne anlaşılması gerektiği maddeler halinde açık bir şekilde belirtilmesi veya kanuni metinlerden çıkarılması gerekmektedir.

\subsubsection{Cezai Hükümler}

Hayvanları Koruma Kanununa aykırı davranılması durumunda verilecek olan idari para cezaları 28. madde de açık olarak belirtilmiştir. Bu cezalar şu şekilde özetlenebilir:

1. Sahip olunan kedi veya köpeğin yavrusunun doğması halinde sahibinin bu yavruları belediyece kayıt edilmemesi halinde yavru başına 300 Türk Lirası,

2. Hayvanları sahiplendikten sonra yaşamlarını sağlıklı bir şekilde devam ettirmesi için gerekli önlemleri almayan kişiler hayvan başına 60 Türk Lirası,

3. Ev ve süs hayvanı üretimini yapıp ticaretini yapan kişilere hayvanların zorunlu ihtiyaçlarını karşılamaması durumda hayvan başına 60 Türk Lirası,

4. Sahip olduğu ev veya süs hayvanlarının doğal yaşama uyum sağlayamayacağını bilmesine rağmen terk eden kişilere hayvan başına 200 Türk Lirası,

5. Sahipsiz hayvanların ve zorunlu ihtiyaçlarını karşılayamayacak derece de güçten düşmüş hayvanları kanunda belirtilen şartlar dışında öldüren kişilere hayvan başına 600 Türk Lirası,

6. Bir hayvan türünün soyunu yok edecek nitelikte davranış gösterenlere hayvan başına 10 bin Türk Lirası,

7. Zorunlu olmadıkça ses tellerinin alınması, kuyruk kesimi gibi hayvanların fiziksel özelliklerini değiştirmek için yapılan her türlü müdahaleler ile hayvanların doku ve organlarının hayvanların yararı gözetilmeden alınması hallerinde hayvan başına 1.200 Türk Lirası,

8. Herhangi resmi yetkisi olmadığı halde hayvanlar üzerinde deney yapan kişilere hayvan başına 1.200 Türk Lirası,

9. Deney hayvanlarının bilimsel olmayan deneylerde kullanan ve deneyler sırasında hayvanın sağlığının korunmasına önem vermeyip bakımlarını yapmayan kişilere hayvan başına 300 Türk Lirası,

10. Kanunda belirtilen şartları gerçekleştirmeden hayvan ticareti yapan ve yönetmeliklerce belirlenen kurallara uymayan kişilere 1000 Türk Lirası,

11. Hayvanı başka bir hayvanla dövüştüren ve il hayvanlar koruma kurullarından gerekli izinleri almadan yapılan geleneksel gösteriler yapan kişilere hayvan başına 1500 Türk Lirası, 
12. Hayvanların kesim işlemlerini hayvanı korkutup acı verecek şekilde veya bu konuda ehliyetli olmayan kişilerin kullanılması durumunda hayvan başına 600 Türk Liras1,

13. Büyük sorunlara sebebiyet verecek durumlar dışında yavrulama, gebelik ve süt annelik durumunda hayvanı öldüren kişilere hayvan başına 600 Türk Lirası, aynı yasağı gerçekleştiren ticari işletmelere ise hayvan başına 1500 Türk Lirası,

14. Hayvanlara kasıtlı olarak kötü davranan ve acı çektiren, hayvanı gücünü aşan işlere zorlayan, 16 yaş altındaki bireylere ev ve süs hayvanı satan, öldüğü kesin olarak anlaşılmayan hayvanın vücudunda müdahale de bulunan, hayvanlarla cinsel münasebette bulunan, hayvana eziyet eden, sağlık amacıyla olmadan hayvana zor kullanarak yem yediren kişilere 300 Türk Lirası,

15. Pitbull ve Terrier gibi insanlar için tehlike teşkil eden hayvanları ülkeye sokan, üretimini gerçekleştiren ve takasını yapan kişilere 3000 Türk Lirası idari para cezaları verilir (TBMM, 2004).

Yukarıda sayılan para cezalarına bakıldığında caydırıcılıktan uzak olduğu açıkça görülmektedir. Hayvanlara yapılan bu tür kötü muameleler devlet kalemlerinin gelir olarak yazacağı bir kapı olarak görülmemelidir. Bu kanunda sayılan küçük miktarlarda idari para ceza öngörülen kanuna aykırı durumlarda kamu düzeninin sağlanması için savcılıklara tam olarak yetki verilmesi gerekmektedir. Ayrıca 5326 sayılı Kabahatler Kanunu çerçevesinde dilencilik yapan ve başkalarının huzurunu bozacak şekilde gürültü yapanlara verilecek olan cezalara benzer miktarda verilen cezaların hayvanlara kötü davranıp işkence yapanlara verilmesi tamamen orantısızlık oluşturmaktadır.

\subsection{Hayvanların Korunmasına Dair Uygulama Yönetmeliği (12.05.2006)}

26166 resmi gazete sayısı ile 2006 yılında yürürlüğe giren Hayvanların Korunmasına Dair Uygulama Yönetmeliği'nde 5199 Sayılı Hayvanları Koruma Kanununa ilişkin detaylı hükümler bulunmaktadır. Sahipsiz hayvanların toplanmasından tedavisinin yapılıp doğaya bırakılması arasında kalan süreçlerinde ilgili kuralları belirleme, sahibi olmayan hayvanların çevreye verecekleri zararın önlenmesinde uygun esasları belirleme, yerel yönetimlerin ve yerel koruma görevlilerin sokak hayvanlarıyla ilgili sorumluluklarının düzenlenmesi ve 5199 sayılı kanuna uyulup uyulmadığının denetlenmesi yönetmeliğin temel amaçları arasındadır. Hayvanların belirli reklam ve gösteri çekimlerine hangi durumlarda konu edilebileceği, hayvanların kamu sağlığını tehdit edebilecek durumlar dışında öldürülmesiyle ilgili esasları, il hayvanları koruma kurullarının esaslarını ve 5199 sayılı Kanunda belirtilen idari para cezalarına ilişkin makbuzların şekli unsurlarını belirlemek yönetmeliğin diğer amaçları arasındadır. 
Hayvanları Koruma Kanununun 5.6.10.13.15.17.18.19 ve 27. maddeleri temel alınarak hazırlanan yönetmeliğin ilk kısmında 5199 sayılı kanuna ek tanımlar yapıldıktan sonra mobil kısırlaştırma ünitesi gibi teknik tanımlara da yer verilmiştir.

Görev ve sorumluluklar başlıklı ikinci kısımda il müdürlüğü, il hayvan koruma kurulu, belediyeler, geçici özel bakımevleri, hayvan sahipleri, sorumlu veteriner hekimler ve yerel hayvan koruma görevlilerinin yetki ve sorumlulukları ayrıntılı bir şekilde belirtilmiştir. Ev ve süs hayvanı satışı yapanlarla yerel hayvan koruma görevlilerine verilecek eğitim ile ilgili düzenlemeler başlıklı üçüncü kısımda yerel hayvan koruma görevlilerin seçimi ve verilecek eğitimle ilgili esasların yanında ev ve süs hayvanı satan kişilerle ilgili esaslara yer verilmiştir. Sahipsiz ve güçten düşmüş hayvanların toplatılması bakılması ile geçici bakımevlerinin çalışma usul ve esasları başlıklı dördüncü kısımda güçten düşmüş hayvanların toplatılma işlemlerinde yetkili kişi ve kurumlar belirtilmiştir. Ayrıca toplama işleminin hangi usullerce yapılması gereği hükme bağlandıktan sonra geçici bakımevlerinde bulunması gereken malzemeler ve bakımevlerinin kurulacağı arazinin nasıl olacağı gibi esaslara yer verilmiştir (TBMM, 2006).

Oldukça ayrıntılı hazırlanan yönetmeliğin diğer maddelerinde ise makbuz ve tutanak düzenlenme esasları, ödenek kullanımına ilişkin esaslar, denetime ilişkin kurallar belirtilmiştir. Hayvanların Korunması Uygulama Yönetmeliği 5199 sayılı Hayvanları Koruma Kanunu'nun genel çerçevesini çizdiği sınırların içini doldurması ve uygulanması esaslarını belirtmesi açısından oldukça önemli bir yönetmeliktir.

\section{5. Çevre Kanunu (11.08.1983) ve Milli Parklar Kanunu (09.08.1983)}

Doğada yaşayan canlıların ortak olarak yaşadığı çevrenin korunması ve sürdürülebilirliğini sağlama amacı taşıyan 2872 Sayılı Çevre Kanunu hayvanların korunmasına yönelik hükümler içeren bir kanundur. Çevre Kanunu'nun 9. maddesi biyolojik ve çevresel sürdürülebilirliğin gerçekleşebilmesi için nesli tehlike altında olan bitki ve hayvanların korunması gerekliliğini vurgulamış ayrıca bu türlerin mevzuata uygun olmayan bir şekilde ticarete konu olamayacağı hükme bağlamıştır (TBMM, 1983). Bu maddede nesli tehlike de olan hayvanlar ifadesi kullanılmış olsa da çevrenin sürdürülebilirliği ve bu hayvanların hayatının devamı doğada bulunan diğer canlıların yaşamına bağlı olduğundan, bu süreçteki tüm canlı sisteminin de hakkını koruyan bir önemli düzenlemedir.

2873 Sayılı Milli Parklar Kanunu'nun 14. maddesi'nde yaban hayatının koruma altına alındığı görülmektedir. $\mathrm{Bu}$ maddede doğanın doğal düzeninin bozulamayacağı vurgulandıktan sonra doğal düzeni bozacak şekilde orman ürünleri tüketilmesi, hayvanların avlanması ve otlatılması yasaklanmıştır. Ayrıca ekosistem çeşitliliğini barındıran sahaların özellikleri bozacak veya değiştirecek her türlü eylem yine aynı maddede yasaklanmıştır (Uyumaz, 2016). 
2. Hayvanların Yaşam Kalitesi ile İlişkilendirilebilecek Diğer Mevzuat Hükümleri

Hayvanların yaşam kalitelerinin belirli standartlara erişmesi ve sağlanan standartların korunması amacıyla yürürlüğe giren temel mevzuat hükümlerinin yanında bu hükümleri tamamlayıcı nitelikte bulunan ek mevzuat hükümleri de bulunmaktadır. Bu başlık altında temel kanunları tamamlayıcı nitelikteki hükümlere bakılacaktır.

\subsection{Köy Kanunu (07.04.1924)}

442 sayılı Köy Kanunu hayvanların ve insanların karşılıklı olarak sağlıklarının korunmasını sağlayabilecek maddeler barındırmaktadır. Köy Kanunu'nun köylünün zorunlu işlerini sıralayan 13. maddesinin 23. fıkrası hayvanlarda salgın bir hastalık görüldüğü anda yetkililere derhal haber verileceği, yetkili gelene kadar hastalığın diğer hayvanlara yayılmasını önlemek ve insanların da zarar görmesinin önüne geçilmesi için hasta hayvanları sağlıklı hayvanlardan ayrılması gerektiğini hükme bağlamıştır. Aynı maddenin 28. fıkrası yıkılma durumunda olan duvarların hayvanlara ve insanlara zarar vermeyecek duruma getirilmesi gerektiğini vurgulamıştır. 34. fıkra ise bir hayvana gücünü aşacak derecede yük yükletilmemesi gerektiği vurgulanmıştır (TBMM, 1924). 1924 yılında yürürlüğe giren ve halen yürürlükte olan bir kanun olan Köy Kanunu olarak hayvanların sağlığına ve korunmasına genel bir bakış açısıyla yaklaşan bir kanun olarak ele alınabilmektedir.

\subsection{Su Ürünleri Kanunu (04.04.1971)}

Türkiye'de kültür balıkçılığı 1970 yılından itibaren gelişmeye başlamıştır. Özellikle 2000 sonrası dönemde hızla artan nüfusun getirdiği aşırı tüketim su ürünlerinin de yoğun bir şekilde tüketilerek bilinçsizce avlanmasına yol açmıştır (Bahadır, Terzioğlu, Didinen, \& Yiğit, 2011). Bu kapsamda deniz ürünlerinin korunması ve kontrol edilmesi için 1971 yılında 1380 sayılı Su Ürünleri Kanunu yürürlüğe girmiştir. Kanunun amacı su ürünlerinin üretimini belirli kurallara bağlayıp korunmasını sağlamaktır. Kanunda su ürünleri ile anlatılmak istenen denizlerde ve iç sularda hayatlarını devam ettiren bitki türleri, hayvan türleri ve hayvan türlerinin yumurtalarıdır. Kanunda deniz suları ve iç sulardaki hayvan türlerinin korunmasıyla ilgili en belirgin hüküm madde 19 da yer almaktadır. Bu maddeye göre kullanıldığı bölgenin ekosistemini olumsuz bir şekilde etkileyecek olan bomba, torpil, dinamit gibi patlayıcı maddelerin kullanılması yasaklanmıştır. Ayrıca elektrik ve elektroşok gibi yöntemlerinin de yalnızca Tarım ve Orman Bakanlığının izni alınarak kullanılacağı belirtilmiştir (TBMM, 1971).

Aynı kanunun cezalar başlığı altındaki 36. maddesinde ise 19. maddeye aykırı hareket edenlerin 1000 Türk Lirası para cezasına çarptırılacağı hükme bağlanmıştır. Su ürünleri sektörü son zamanlarda et fiyatlarının artması ve zengin protein içeren ürünlere sahip olması nedeniyle yoğun olarak tercih edilen bir sektör olmaktadır 
(Çavdar, 2009). Balık ve diğer denizsel kaynaklı ürünlerin özellikle kış mevsiminde yoğun bir şekilde tüketilmesinden dolayı denizlerdeki hayvan türleri yoğun bir tehlike ile karşı karşıya kalmaktadır. Bu hayvan türlerinin sürdürülebilirliğinin sağlanması ve deniz faunası ile florasının korunması açısından bu tip kanun hükümleri büyük önem taşımaktadır.

\subsection{Veteriner Hizmetleri, Bitki Sağlığı, Gıda ve Yem Kanunu (11.06.2010)}

Ulusal mevzuat da hayvanların yaşam kalitesi ile ilişki kurulabilecek diğer bir kanun 5996 sayılı Veteriner Hizmetleri, Bitki Sağlığı, Gıda ve Yem Kanunu'dur. Bu kanunun amacı gıda ve yem güvenliğini sağlayarak halk, bitki ve hayvan sağlığının yanında çevreyi korumaktır. Kanun genel olarak incelendiğinde hayvan sağlı̆̆ını olumsuz etkileyecek veya etkileme şüphesi olan yemlerin hayvanlara verilmesini yasakladığı görülmektedir. Hayvan sağlığına olumsuz etki eden ürünlerin tespit edilmesi halinde derhal piyasadan toplanacağı ve mülkiyetine kamunun el koyacağı belirtilmiştir. $\mathrm{Bu}$ ürünlerin piyasaya girişine neden olan kişilere de Veteriner Hizmetleri, Bitki Sağlı̆̆ı, Gıda ve Yem Kanunu'nun 40. maddesine göre 5 bin Türk Lirası idari para cezası verileceği hükme bağlanmıştır (TBMM, 2010). 5199 sayılı Hayvanları Koruma Kanun'unda yoğun eleştiriye maruz kalan caydırıcı olmayan cezalarla bu kanunda da karşılaşılmaktadır. Bu tip maddelerin daha caydırıcı nitelikteki maddelerle değiştirilmesi gerektiği düşünülmektedir.

\subsection{Türk Silahlı Kuvvetleri İç Hizmet Kanunu (09.01.1961)}

211 sayılı Türk Silahlı Kuvvetleri İç Hizmet Kanunu'nda doğrudan hayvanların yaşam kalitesini geliştirmeye yönelik hükümler bulunmaktadır. Kanunun hayvanlara ait bakım ve hizmetler başlığı altındaki 71. maddesinde hayvanların bakımının ve gerekli ihtiyaçlarının kurallara uygun olarak yerine getirileceği belirtilmiştir. 72. maddesinde ise hastalanan hayvanların zaman kaybetmeden TSK bünyesinde çalışan veteriner hekimlere götürülüp tedavisinin yapılması gerektiği hükme bağlanmıştır. Kanunda ayrıca TSK bünyesinde çalışmış olan fakat çalışma gücünü yitiren hayvanların sahiplendirileceği, sahiplendirilme gerçekleşmemesi durumunda ise barınma yiyecek ve sağlık giderlerinin Milli Savunma Bakanlığı, Jandarma Genel Komutanlığı veya Sahil Güvenlik Komutanlığı Bütçelerinden karşılanacağı hükme bağlanmıştır (TBMM, 1961). Hayvan hakları boyutuyla düşünüldüğünde Türk Silahlı Kuvvetler bünyesinde çalışan hayvanların çalışma gücünü kaybettiğinde doğada yalnız bir şekilde bırakılmaması bu kanunun olumlu yönünü oluşturmaktadır. Tüm hayatı boyunca insanlarla iç içe yaşayan bir hayvanın aniden yalnız bırakılması kent içerisinde yaşayan insanlara zarar verebilme ihtimali bulunmaktadir.

\section{5. İcra ve İflas Kanunu (19.06.1932)}

2004 sayılı İcra ve İflas Kanunu'nda hayvanlara insanların geçimini sağlayacak bir araç olarak bakılsa da dolaylı olarak hayvanların sağlığını korumaya yönelik 
hükümler de içermektedir. Haczi yapılamayacak olan mallar ve haklar başlı̆̆ altındaki 82. madde de haciz sırasında borçlunun seçeceği bir büyükbaş veya üç küçükbaş hayvanın haczedilemeyeceğine ek olarak bu hayvanların yaşamlarını sürdürecekleri üç aylık yem ve yataklarının da haczedilemeyeceği hükme bağlanmıştır. Bu maddeyle haczi kabul edilmeyen hayvanların kısa bir sürede zor durumda kalmasının engellenmesine çalışıldığı görülmektedir. Kanunun yavru hayvanların haczi başlıklı 83. maddesinin 2. fıkrasında ise anne bakımı olmadan yaşayamayacak yavruların anneden ayrı haczedilemeyeceğini yine yavrusuna bakma durumunda olan annenin yavrulardan ayrı haczedilemeyeceği hükme bağlanmıştır (TBMM, 1932). Yürürlüğe giren bu maddeyle haciz nedeniyle yavrunun yaşamının tehlikeye girmesinin engellenmesi hüküm altına alınmaya çalışılmıştır.

\section{Sonuç}

5199 sayılı Hayvanları Koruma Kanunu Türkiye'de hayvan hakların korumak için yürürlüğe giren ilk kanundur. 2004 yılında yürürlüğe giren 5199 sayılı kanun o günün koşullarında hayvan haklarını geliştirmesi ve bu amaçla sokak hayvanlarının kısırlaştırılması, tedavilerinin yapılması, bakımevlerinin işleyişi gibi konularda merkezi yönetim ve yerel yönetimlerin sorumluluklarını belirlemesi açısından önemli bir başlangıçtı. Ancak 5199 sayılı kanun günümüzde Türkiye'nin ihtiyaçların karşılamaktan oldukça uzak, güncellenmesi gereken bir kanun olarak karşımıza çıkmaktadır. Çeşitli sivil toplum örgütleri tarafından da sık sık dile getirilen günün koşullarına göre güncellenme ihtiyacı özellikle kanunun cezalar, denetleme ve hayvanlara bakış açısında kendisini göstermektedir. Sokak hayvanlarının yaşam kalitesinin arttırılması için 5199 sayılı kanunun yeniden gözden geçirilmesi gerekmektedir.

5199 sayılı kanunla bağlantılı olan diğer önemli kanun da 5237 sayılı Türk Ceza Kanunudur. 5237 sayılı kanunun sokak hayvanlarının yaşam kalitesinin arttırılması ve haklarının tam anlamıyla güvenceye alınabilmesi için sahipli ve sahipsiz hayvan ayrımının yapılmaması gerekmektedir.

5199 ve 5237 sayılı kanunlara ek olarak ifade edilen diğer kanunlarında hayvanların yaşam kalitesini arttırıcı şekilde revize edilmesi gerekmektedir. Mevzuat hükümlerinin hayvanlara sahip olunan eşya olarak değil, bir canlı olarak bakması daha doğru olacaktır.

\section{Kaynakça}

Albayrak, M. (2008). Şikâyete Tabi Suçların Özellikleri ve Bu Suçlara Bağlanan Hukuki Sonuçlar. Türkiye Barolar Birliği Dergisi(77), 282-284.

Bahadır, S., Terzioğlu, S., Didinen, B. I., \& Yiğit, N. (2011). Sürdürülebilir Su Ürünleri Yetiştiriciliğinde Çevre Dostu Üretim. Ankara Üniversitesi Çevrebilimleri Dergisi, 3(1), 107-113. 
Çavdar, Y. (2009). Su Ürünleri Yetiştiriciliğginde Desteklemeler. Yunus Araştırma Bülteni(4), 12-14.

Dönmez, B. (2013). Hayvanlara Yönelik İşlenen Suçlar. Yaşar Üniversitesi Dergisi(Özel), 213-214.

Ege Orman Vakfı. (2015). 08 03, 2019 tarihinde www.egeorman.org.tr Web Sitesi: https://www.egeorman.org.tr/images/belgeler/ormanlar_yasam_kaynagidir.pdf adresinden alındı

Erişgin, Ö. S., \& Koçhisarlıoğlu, C. (2003). Hayvanın Hukuki Konumu. Yaşar Üniversitesi Dergisi, 8(Özel ), 1691-1723.

Gürkan, Ş., \& Uğuz, A. (2007). Yeni Ceza Yasamızda Cinsel Suçlar. Adalet Dergisi(27), 179.

Gürocak, İ. (2011). Türk Ceza Kanunu'nda Mala Zarar Verme ve İbadethanelere ve Mezarliklara Zarar Verme Suçları(94), 159.

Özgür, A. (2010). Türk Hukuk Sisteminde Hayvanlar. Veteriner Hekimler Derneği Dergisi(81), 33.

Özmen, R. (2012). Anayasa, Türk Ceza Kanunu, Ceza Muhakemesi Kanunu ve İnfaz Капипu (38. b.). Ankara: Seçkin Yayıncllık.

Parlar, A., \& Hatipoğlu, M. (2007). 5237 Sayılı Türk Ceza Kanunu Yorumu. Ankara: Seçkin Yayıncılık.

Pounting, C. (2008). Dünyanın Yeşil Tarihi - Çevre ve Büyük Uygarlikların Çöküşü. İstanbul: Sabancı Üniversitesi Yayınları.

Tamzok, H., Kük, M., \& Çobanoğlu, N. (2013). Hukuki ve Etik Boyutlarıyla Sokak Hayvanları (Cilt 4). Ankara: Ankara Üniversitesi Sosyal Bilimler Enstitüsü Dergisi.

TBMM. (1924, 03 18). 442 Sayıl Кӧу Капипи. 10 01, 2018 tarihinde http://www.mevzuat.gov.tr/MevzuatMetin/1.3.442.pdf adresinden alınd1

TBMM. (1932, 06 09). 2004 Sayll İcra ve İflas Kanunu. 10 21, 2018 tarihinde http:/ / www.mevzuat.gov.tr/MevzuatMetin/1.3.2004.pdf adresinden alındı

TBMM. (1961, 01 04). 211 Sayılı Türk Silahlı Kuvvetleri İç Hizmet Kanunu. 09 03, 2018 tarihinde http://www.mevzuat.gov.tr/MevzuatMetin/1.4.211.pdf adresinden alındı

TBMM. (1971, 03 22). 1380 Sayılı Su Ürünleri Капипu. 09 17, 2018 tarihinde http:/ / www.mevzuat.gov.tr/MevzuatMetin/1.5.1380.pdf adresinden alınd1

TBMM. (1983, 08 11). 2872 Sayll Çeore Капипи. 10 14, 2018 tarihinde http:/ / www.mevzuat.gov.tr/MevzuatMetin/1.5.2872.pdf adresinden alınd1

TBMM. (2004, 07 01). 5199 Sayılı Hayvanları Koruma Капипи. 10 21, 2018 tarihinde http://www.mevzuat.gov.tr/MevzuatMetin/1.5.5199-20100611.pdf adresinden alındı 
TBMM. (2004, 10 12). Türk Сеza Капипu. 10 12, 2018 tarihinde http://www.mevzuat.gov.tr/MevzuatMetin/1.5.5237.pdf adresinden alınd1

TBMM. (2006, 05 12). Hayvanların Korunmasına Dair Uygulama Yönetmeliği. 10 21, 2018 tarihinde http://www.mevzuat.gov.tr/Metin.Aspx?MevzuatKod=7.5.10300\&MevzuatIliski $=0 \&$ sourceXmlSearch $=$ hayvanlar $\% \mathrm{C} 4 \% \mathrm{~B} 1 \mathrm{n} \% 20$ korunmas $\% \mathrm{C} 4 \% \mathrm{~B} 1 \quad$ adresinden alınd 1

TBMM. (2010, 06 11). 5996 Sayılı Veteriner Hizmetleri, Bitki Sağhlğı, Gıda ve Yem Капипи. $10 \quad 17, \quad 2018 \quad$ tarihinde http://www.mevzuat.gov.tr/MevzuatMetin/1.5.5996.pdf adresinden alındı

Türkiye Büyük Millet Meclisi. (1982, 11 09). Türkiye Cumhuriyeti Anayasası . 10 20, 2018 tarihinde http://www.mevzuat.gov.tr/MevzuatMetin/1.5.2709.pdf adresinden alınd 1

Uyumaz, A. (2016). Bir Hukuk Sorunsalı Olarak Güncel Gelişmeler Işı̆̆ında Türkiye' de Hayvan Hakları. Gazi Üniversitesi Hukuk Fakültesi Dergisi,(3), 171.

Yılmaz, H. (2006). Hayvan Haklarına Bakış. Türkiye Barolar Birliği Dergisi(62), 219220. 